\title{
The Formation of Behavioral Leadership Competencies of Future Officers of the Armed Forces of Ukraine
}

\author{
O. V. Boyko \\ Hetman Petro Sahaidachnyi National Army Academy, Lviv, Ukraine \\ Corresponding author. E-mail: olegboyko69@gmail.com
}

Paper received 10.03.20; Accepted for publication 08.04.20.

\section{https://doi.org/10.31174/SEND-PP2020-227VIII91-02}

\begin{abstract}
The methodology of the formation of the behavioral leadership competencies of future officers in the course of basic vocational training is grounded in the article. It is determined that when using the competence-oriented approach the behavioral competencies are dominant in the implementation of programs for the formation and development of leadership potential in the system of vocational training of servicemen of the Armed Forces of Ukraine. The author believes that the competence can determine the behavior of a military specialist in certain professional (educational, service, combat) situations. However, this is not the reduction of behavior only to the totality of motor reaction in response to the effect of external stimuli. Ignoring the social nature of a human being and the presence of consciousness did not allow behavioralists to disclose the nature and peculiarities of human behavior. It is not simply an automatic reaction to an active stimulus, but it is regulated by its consciousness on the basis of the assessment of the situation and socially established norms. The article investigates that the main behavioral competencies of the leader of the military unit of the primary tactical level of management (division, platoon, and company) can be as follows: proactivity, self-confidence, adaptability and flexibility, aspiration to improve both himself and subordinate stuff and the processes professional activity in it, creativity, non-complexity of thinking, initiative, autonomy, vision of perspective and effective ways of achieving the goals set, persistence, tranquility communicability, readiness to assume responsibility for own decisions and actions, etc. The methodology based on the leading ideas of the concepts of competency and subject-activity training of servicemen is disclosed and the most rational and effective methods, techniques, forms of the formation of the leadership competences of military specialists in obtaining their professional education are included, namely: the acquisition of positive attitudes, instructions, experience, skills of the future military leader, which enable him to carry out consciously this activity with the greatest efficiency.
\end{abstract}

Keywords: competency, competence, methodology, behavioral leadership competencies, behavior indicators, leader's reaction.

Introduction. The system of professional training of servicemen of the Armed Forces of Ukraine requires the solution of the problem of experimental research, the scientific substantiation, the implementation and standardization of modern methods of forming behavioral leadership competencies as one of its components.

The actual practical task of professional training of future officers (sergeants) is training experience to be acquired by them in functional situational leadership, effective imitation of behavioral reactions of a military leader, group and individual solution of interpersonal conflicts, individual and group responsibility, organization of communication and interaction in the process of carrying out educational (service, training-combat) tasks, etc.

Structural and logical analysis of the results of scientific researches of this problem testifies that there are multidisciplinary approaches to its solution: philological, psychological, pedagogical and educational. First, we justify the conceptual categorical apparatus of the goal set out in the article.

The brief review of related publications. According to V.V. Yagupov in the manual "Military didactics", the concept of "methodology" - defines the specific forms and means of using methods, through which the deeper knowledge of various pedagogical problems and their solution is performed. [1, p. 357].

In our opinion, the idea of adaptive and flexible management of the didactic process, creative design of its content and reproduction of the training cycle according to the defined goals should be at the heart of any methodology for training military specialists [2]. The properties of this technique are aimed at overcoming the disadvantages of traditional vocational training, so, according to almost all researchers of this problem, one of the most important properties of any technique is the ability to reproduce it.

The term "competence" is more old-established than the concept of "competency" for their application in the education system, in particular in the field of professional training of specialists. Both words come from Latin word "compete", which means "answer", "fit". Accordingly, the Latin word "competens" means "capable," "eligible". Looking out the words in the dictionaries, according to V.I. Lugovyi gives the following results: "Competence is authority, experience. Competent - qualified. Competency - 1) quality; 2) the terms of reference " [3, p. 10].

Ukrainian scientists V.V. Yagupov and V.I. Svystun propose the following definition of "competence": "Competence is the readiness (theoretical, practical, personal, psychological, etc.) to carry out a certain professional activity and the presence of professionally important qualities of a specialist which contribute to this activity" $[4$, p. 6].

It is important for theoretical analysis and practical application to understand the interdependence between the concepts of "competence" and "competency", which is as follows: "Competence is the result of the acquisition of competencies" [5, p. 20].

So, from our perspective, competencies are components of competence that, in particular, are defined as key personality traits that are important for the effective performance of the functions of an activity in a particular position and can be measured by observing person's behavior. In our case, it is a manifestation of the officer's leadership behavior in various professional situations. That is, leadership competency determines (encourages, manifests) the behavior of a military leader.

The main aim of the article is to substantiate the methodology of forming leadership behavioral competencies of future officers (cadets of higher military educa- 
tional establishments using special training tools during their "Leadership Response Course".

The materials and methods. We believe that the competency can determine the behavior of a specialist, including the military in certain professional (training, service, combat) situations. However, this is not a reduction of behavior only to a set of motor reaction in response to the action of external stimuli. Ignoring the social nature of a man and the presence of consciousness did not allow behaviorists to reveal the nature and peculiarities of human behavior. It is not a simple automatic response to an active stimulus, but it is regulated by its consciousness on the basis of an assessment of the situation and socially established norms [6, p. 254-255].

We emphasize that competencies are personal characteristics of a person that determine his or her behavior and influence the level of performance of certain (including professional) activities. Consequently, competence is the result of the acquisition of competencies, and competencies are the component of competence.

We have to note that we adhere to the following logic in categorical approaches: "competence cluster" (competence containing 2-5 competencies) - "competency" "behavioral indicators" (3-6 for each competency). Behavioral indicators are defined by us as the smallest units used to monitor competencies. The assessment of the competencies is based on the identification of indicators that indicate the presence or absence of appropriate behavioral competency and its level.

To illustrate the correlation between the basic concepts of a competence-oriented approach, we use the following association: the behavioral indicators are similar to "atoms"; competencies are similar to the "elements" described by several behavioral indicators; competency clusters correspond to so-called "macromolecules".

Going from smaller to bigger, we get the following chain of competence oriented approach: indicator - indicators - competency - competencies - competence competences.

In many scientific sources dedicated to a competencyoriented approach, great attention is paid to identification of the existing competences (the plurality of "competence") and their types.

Consequently, the phenomena defined by the concepts of "competence", "competency" and "competence approach in education" cannot exist individually, since each of these concepts is a semantic continuation of the other: competency as a scientific phenomeno-competence as an integral quality, which characterizes the readiness of a particular specialist to address certain competencies - a competent approach as the realization of this integral professionally important quality (behavioral competencies, ability) in the practical activity of a military professional, including leadership activity [4].

We now turn to the basic competencies of a military leader. We identify five of the following behavioral competencies:

1. Motives. This is what the military leader thinks or wants; which causes the action. Motives target and guide the behavior of a military leader for action.

2.Psychophysiological features (or properties). Mental and physical characteristics and response of a military leader to situations or information.
3. "I-concept". The attitudes, values, or image of the "I-human" of a military leader.

4. Skills. The ability of a military leader to perform a specific physical and mental task.

5. Knowledge. The information possessed by a military leader in certain substantive areas [7].

It should be mentioned that the proposed types of competencies of a military leader are clearly correlated with the well-known model of competence by J.M. Leclerc and a four-step model of military specialist competence development [8, p. 92].

For instance, according to certain levels, we identify three major types of military leader competencies:

- knowledge based - in the form of available knowledge;

- skills based - in the form of available skills;

- behavioral (motives, features, values, traits, attitudes) - in the form of available motives, psychophysiological qualities, values, attitudes.

We focus our attention on the methodology of forming behavioral competencies, explaining this choice by:

- the methods of developing knowledge and exercise competencies are well known to the educational community, while methods of developing behavioral competencies are only included in the training process of servicemen of the Armed Forces of Ukraine;

- it is important not only to recognize and bring to the level according to knowledge and skills the behavioral competencies of the individual, but to recognize them as crucial for ensuring the effective usage of the acquired knowledge and skills of the cadets of higher military educational establishments;

- behavioral competencies are dominant in the implementation of leadership development programs in the system of professional training of military personnel of the Armed Forces of Ukraine.

The formation and development of behavioral leadership competencies of future officers in the course of their professional training is not a well-researched area of Ukrainian military-pedagogical science both theoretical and practice. However, it is closely linked to the achievements of military psychology and rests on a psychological and pedagogical basis. In particular, prospective niches for research are the identification and description of behavioral competencies, their detailing at the level of indicators, and the like.

The success of tasks (combat, training, etc.) is determined by the behavior of a military leader. That is why behavioral indicators are the minimum unit of competence approach in the training of military leaders. These indicators allow to set the level of evaluative competence.

Taking into the consideration the findings and summuries of the mentioned above studies, we believe that the primary behavioral competencies of the leader of the military unit of the primary tactical management unit (department, platoon, company) may be: proactiveness, self-confidence, adaptability and flexibility, desire to improve both personally himself and the subordinate staff and processes of professional activity in it, creativity, unframed thinking, initiative, independence, vision of perspective and resultative ways in achieving set goals, persistence, balance, sociability, willingness to take responsibility for taken decisions and actions, etc. 
The general educational means (objects of the educational and material base of vocational training) of forming behavioral leadership competencies of servicemen of the Armed Forces of Ukraine in modern conditions are as follows: training grounds, shooting ranges, operating (or models) of weapons and military equipment, training equipment, educational literature, specialized classrooms, obstacle courses etc.

Taking into the account the defined set and standardization of leadership competencies and their indicators, the generalized experience of organizing the selection and training of military leaders in the partner countries' armies [9], "Leader Reaction Zone" have been created in the training centers of the Ukrainian Armed Forces, which are the basic training and material resources for those who attend the "Leadership Reaction Course".

The results and its discussion. One of the most important aspects of leadership is that without action, nothing can change. Therefore, the training of future officers through action is accomplished by performing special situational tasks on the elements of the "Leader Reaction Zone". Learning through action is seen as an effective way of forming leadership, because during its implementation the participant in the training process gets the opportunity to improve his leadership behavior and, consequently, to acquire and develop his behavioral competencies.

There are different ways to train future military leaders through activities. However, in the "Leadership Response Course", instructors mostly use coaching. According to M. Landsberg, the coaching structure ("GROW" model) includes the following steps:

1. "G" - goal. It is the process of choosing by an instructor (coach) and his / her under guardianship a specific problem to discuss and determine the ultimate purpose of the discussion.

2. "R" - reality. The coach and the under guardianship give an assessment of the situation and give specific examples to confirm their vision.

3. "O" - options. The ways to solve a particular problem are proposed and the most constructive ones are selected.

4. "W" - wrap-up. Instructors and mentees develop an action plan, set time limits for achieving the desired results, discuss and implement ways to overcome potential problems that may arise [10, p. 43-47].

In the "Leadership Response Course" instructors use the training cycle for the preparation of military leaders with the following phases: goal setting (situational tasks) - immersion in reality - developing options for solving situational problems - flexible and adaptive implementation of the intended - evaluation - analysis of actions carried out (After Action Review) - actions improvement. Thus, the features of the course methodology are highlighted below.

The course duration may vary, but it typically involves up to 16 situational tasks performed on specially equipped elements of the "Leader Reaction Zone". For example: "Out Like Flint", "Rope Bridge", "Double Culvert", "Mine Field", "Bulk Sands", "Destroyed Bridge", "Wall Banger", and more.

The training group consists of 6 to 8 people to complete a single task for a limited period of time. The equipment needed for each situation is limited and some materials may not be needed. For most situational tasks, the group leader is assigned by an instructor. The successful completion of a situational task requires interaction and communication, mental and physical labor, and can push a group or individuals to move beyond their previously known boundaries. In addition, the course also provides motivation, a sense of accomplishment and positive support for effective teamwork.

The main varieties of situational tasks performed on the elements of "Leader Reaction Zones" are: "Escape", "Sabotage", "Ho Chi Minh Trail", "Barrel Rolling", "Rock Climber", "Medical Evacuation", "Undermining" and more.

An important role in evaluating by an instructor (coach) of each military leader is played by stress. Therefore, in order to model a stressful environment, the workgroup should be subject to some restrictions. The team cannot touch something painted black, go beyond the set task, or touch the mulch territory under certain obstacles. They work with particular time constraints usually 12-15 minutes per one situational task (exact time constraints can be adjusted to change the level of difficulty). Instructors (coaches) have 2 minutes to instruct briefly the assigned leader or group before starting each task. The only equipment that the team can use is the one which is provided. The usage of sound stimulus (effects) and smoke by instructor groups increases stress. This is an attempt to distract the training group while performing a situational task and to cause confusion and chaos in the actions.

Course adjustments can be made to focus on the following learning goals: individual leadership development and assessment; development of a small coordinated combat unit; increasing or strengthening of subordination; determining the organizational effectiveness of small units in completing a task, etc.

The instructors (coaches) of the course have a learning purpose which is to gain maximum leadership experience for those who study. They must:

- to create an atmosphere in each individual training group that would encourage open interaction and analysis of the actions among all participants in the activity;

- to understand the desirable leadership experience for further tracking of its growth; to eliminate recourse and identify changes in individual and group actions;

- to analyze critically the actions of the group after each completed task, providing an assessment of the performance of the group members and encouraging them to self-analyze the actions;

- to highlight any aspects of the situational tasks that are not observed by the group itself, etc.

By watching and critiquing, instructors (coaches) improve their own methodological skills and experience in assessing leadership, imitation, and group dynamics. In addition, the instructors' team will practice and develop methodological skills in interviewing, counseling, coaching, personal responsibility, group motivation and communication.

Instructors (coaches) in the process of completing situational tasks during the process of "Leader Reaction Zones" by those who learn, use the following methodological guidelines: 
1. Leadership behavior (competencies, indicators) of the designated senior of a training group, his style and contingencies (if not specified). How and why was this particular soldier selected?

2. The emergence of an informal leader? How and why did this situation arise?

3. Brainstorming. Are all members of the training team involved in the task? Why and why not?

4. Distribution of roles in the training group. Allocation of resources by manifested leadership competencies (indicators).

5. Compliance with the rules. If not, why did it happen?

6. Duration of the situational task and efficient use of time.

7. Interpersonal relationships and conflicts. If so, how are they resolved?

8. Group behavior - being active against being passive, effective followers of a designated leader? Did everyone understand the situational task to be accomplished?

9. Obstacles or problems encountered. How to solve them? Was the plan, leader and group selected flexible and adaptive?

10. Communication templates. What was the feedback? Vertical? Horizontal? Whose responsibility is it?

11. Are the standards of discipline kept to, and what about display of team spirit, positive stimulation (praise), criticism, motivation, interaction? How is this happening?

12. Equality of participation in the implementation of the situational task. Does anyone feel out of process? Why?

13. The process of internal communication in a training group. Did they know each other's names? How did it affect communication and group dynamics?

14. What is the optimal size of the training group? What are some examples of loss of leadership process in a training group?

15. What to do with members of the training team who did not understand what was happening: ignore, repeat, demonstrate, prompt, criticize? Was the reaction to them effective?

When organizing an informal analysis of actions, instructors (coaches) use the following questions to stimulate those who are critical thinking learners:

1. How can this learning experience be connected to the real world?

2. If you could describe your experience in one word, what word would it be and why?

3. Think of the best team you've ever been to. On a scale of 1 to 10 (10 is the best), how would you evaluate your team's performance today?

4. Has your team used the time effectively? What percentage of time was spent on planning and completing the task? How did it affect the success of the team?

5 . What actions helped or hindered your group? What will you do differently next time?

6. What is the most important thing you learned about yourself today?

The instructors (coaches) remind the training groups (teams) to maintain a high level of personal and group awareness, as well as all aspects of the safety alert throughout the course.

Each situational task has a 15-minute deadline for completion. However, this may be adjusted depending on the group's effectiveness and the instructor's experience. High-performing training teams can take advantage of additional time constraints to increase the complexity of the task and facilitate the process of leadership behavior.

The staff at the observation (working) bridge should not assist the training group in any way and the group may receive a penalty time for using such assistance. However, if there is a danger to the group members seen from the workplace, it should be reported immediately.

Depending on the format and purpose of the course, instructors (coaches, assessors) may briefly instruct designated leaders (seniors) of the study group (team) separately from other participants before completing each situational task. This activates the need and leads to closer communication between the potential leader and the rest of the group members, assessing his or her ability to understand and to accomplish the tasks.

Instructors (coaches) play the role of facilitators in assessing deficiencies. But at the same time, they create a non-punitive, comfortable atmosphere, aimed at positive attunement and motivation to perform situational tasks.

Many of the situational problems have spelled out solutions, but there are often options that will be solved not by patterns. Instructors (coaches) should not attempt to correct the actions of the training group if they are working on an alternative solution, but they stop the situational task if the technique of its implementation is dangerous.

Assessment by instructors (coaches) of behavioral leadership competencies of learners is performed on the basis of criteria and indicators defined in the evaluation sheet for each situational task. Generalized indicators determine the level of their formation of each serviceman who is trained in the "Leadership Response Course".

Discussion questions on the implementation of the methodology of formation of leadership competencies for future officers (sergeants) may be:

- to study the experience and implementation of a unified system of training of coaches and their certification for conducting the "Leadership Response Course";

- to create of a universal profile (card) of leadership competencies (indicators) without taking into account the specificity of professional activity in a particular military specialty (accounting specialty);

- to modify situational tasks when passing standardized elements of "Leader Reaction Zones" in accordance with the specifics of military specialty;

- to develop and justify the system of assessment of team work of the training group and its levels of cohesion in the process of performing situational tasks on the "Leader Response Strip", etc.

Conclusions. The methodology of forming leadership competencies of future officers of the Armed Forces of Ukraine in the narrow sense is a theoretically substantiated didactic system. The purpose of which is the development of value-motivational, emotional-volitional, praxological and subjective components of their leadership competence that show the reliability of their mental health in the conditions of professional activity and ensure the fulfillment of assigned tasks by appointment in the tactical link of military management.

Thus, the article exposed some aspects of the training system, which is based on the leading ideas of the con- 
cepts of competence and subject-based training of military personnel and includes the most rational and effective methods, techniques, forms of formation of leadership competencies of military specialists in their acquisition of professional education.
In the process of their formation, they acquire positive attitudes, experience, skills of the future military leader, which enable him to consciously carry out this activity the most effectively in military units.
1 Ягупов В.В. Військова дидактика. Київ, 2000. 400 с.

2. Бойко О.В. Формування готовності до управлінської діяльності у майбутніх магістрів військово-соціального управління: дис. ... канд. пед. наук: 13.00.04 / Національна академія оборони України. Київ, 2005.

3. Луговий В.І. Компетентності та компетенції: поняттєвотермінологічний дискурс. Вища освіта України. 2009. № 3. C. $8-14$.

4. Ягупов В.В., Свистун В.І. Компетентнісний підхід до підготовки фахівців у системі вищої освіти. Наукові записки Національного університету “Києво-Могилянська академія". 2007. Том 71. С. 3-8.

5. Овчарук О.В. Компетентнісний підхід у сучасній освіті: світовий досвід та українські перспективи. Київ, 2004. $112 \mathrm{c}$.

\section{LITERATURE}

6. Степанов О.М. Психологічна енциклопедія. Київ, 2006. $424 \mathrm{c}$.

7. Бойко О.В. Теоретико-методичні проблеми формування лідерської компетентності майбутніх офіцерів Збройних Сил України: монографія. Львів, 2014. 543 с.

8. Калашнікова С.А. Освітня парадигма професіоналізації управління на засадах лідерства: монографія. Київ, 2010. $379 \mathrm{c}$.

9. Compton H. Leadership Reaction Course and Problem Solving. Marine Military Academy Blog URL: https://www.mmatx.org/blog/2580/marine-military-academy-leadershipreaction-course/ (Last accessed: 17.07.2019).

10. Ландсберг М. Коучинг. Повышайте собственную эффективность, мотивируя и развивая тех, с кем работаете. Москва, 2004. 160 с.

\section{REFERENCES}

1. Yahupov, V.V. (2000). Military didactica. Kyiv [in Ukrainian].

2. Boiko, O.V. (2005). Formation of readiness for management activities in future masters of military and social management. Candidate's thesis. Kyiv: NUOU [in Ukrainian].

3. Luhovyi, V.I. (2009). Competence and competences: conceptual-terminological discourse. Higher education of Ukraine, 3, 8-14 [in Ukrainian].

4. Yahupov, V.V., \& Svystun, V.I. (2007). Competent approach to training specialists in the system of higher education. Scientific notes of the National University "Kyiv-Mohyla Academy", 71, 3-8 [in Ukrainian].

5. Ovcharuk, O.V. (2004). Competency approach in modern education: world experience and Ukrainian perspectives. Kyiv [in Ukrainian].

6. Stepanov, O.M. (2006). Psychological Encyclopedia. Kyiv [in Ukrainian].

7. Boiko, O.V. (2014). Theoretical and methodical problems of forming the leadership competency of future officers of the Armed Forces of Ukraine. L'viv [in Ukrainian].

8. Kalashnikova, S.A. (2010). Educational paradigm of management professionalism on the basis of leadership. Kyiv [in Ukrainian].

10. Landsberh, M. (2004). Increase your own efficiency by motivating and developing those with whom you work. Moscow [in Russian]. 